\section{Old Saskatchewan Stone Age Relics}

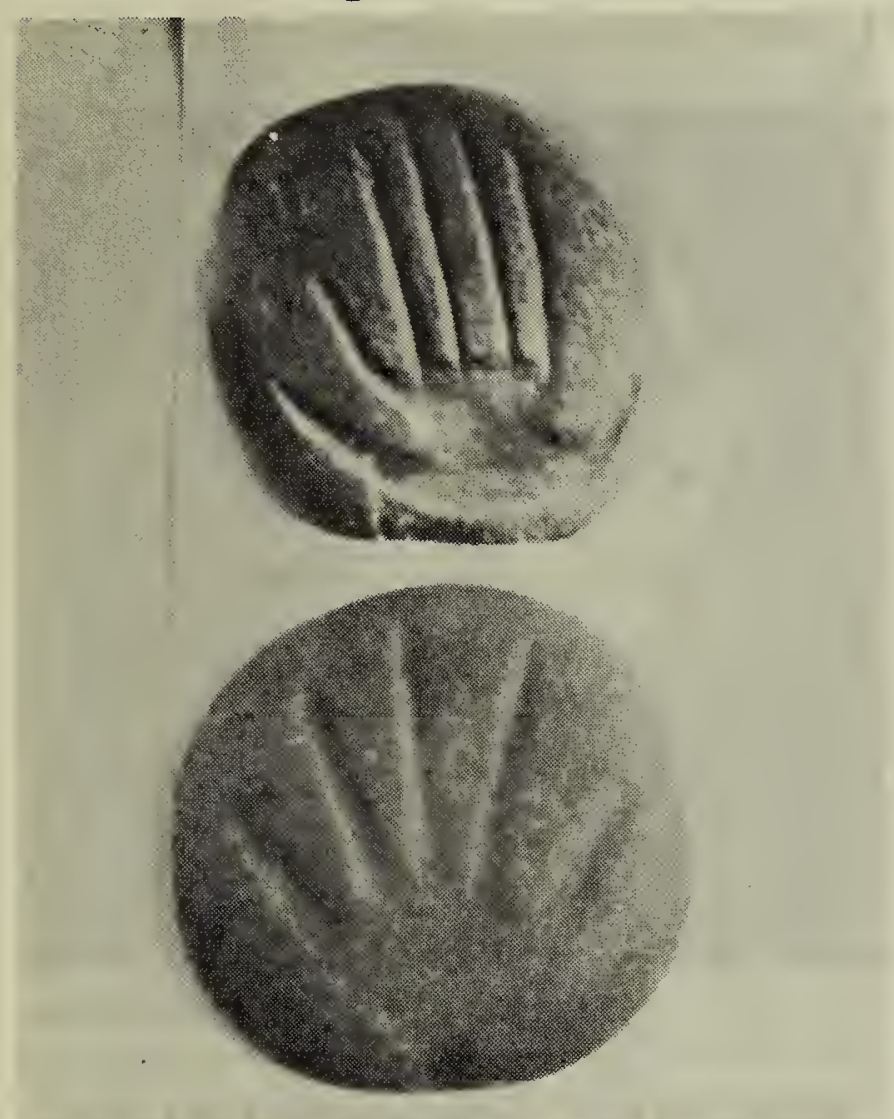

Above are two of the rarest stone relics found on these plains. Can anyone suggest what these eight inch diameter disks were used for?

\section{Limestone Artifact}

A very interesting letter came to the editor during September from J. M. Provick, Hazelcliffe, Sask. Mr. Provick describes an artifact he found in the Welwyn district and which is quite a puzzle to him. It is fashioned from limestone, well rounded, three inches in diameter with one end pointed and the other flat or quite blunt. It is quite smooth showing considerable use. He asks for an opinion as to what it may have been used for.

Editors note: Limestone relics are quite rare. The pointed top suggests it is a pestle, also a rare item in Western Canada. Its' size and diameter also seem to suggest pestle.

\section{TO A PANSY}

Oh, pansy purple with heart of gold!

I wonder often when I'm told

That you are only but a flower

For to me you seem a face, That smiles upon out human race. -Mrs. Keith D. Paton

\section{Prehistoric Bones}

By Vernier Rondeau, Rouleau, Sask.

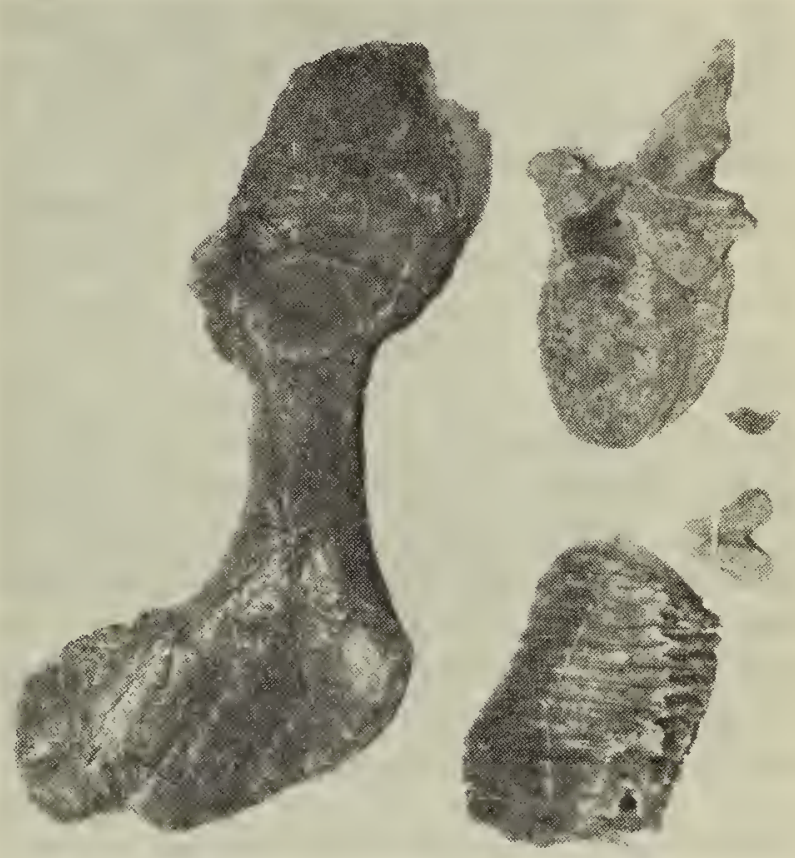

Some years ago I was on a holiday at Katepwa. While there I came across some mammoth bones which were found in a gravel pit by some Metis workers. I acquired the bones from them. These are shown in the photograph. The top bone is a hip bone. It is about two feet long and weighs fourteen pounds. The tooth on the right weighs seven pounds. The vertebrae is one foot from tip to tip. It weighs three and one half pounds.

The tiny tooth is of a prehistoric horse and the bone near same belongs to the same animal and is part of the backbone.

I donated the vertebrae to the Moose Jaw museum.

\section{Prince Albert Natural History Society}

The Prince Albert Society brought to the annual meeting of the Saskatchewan Natural History Society this interesting report of activities. This year it has organized five field trips (one in April, three in May, and one in October). It sponsored a series of five Audubon tours in 1954-55, and began a new series this fall with an attendance of 300 at the first lecture. In addition, it has held two general meetings and seven executive meetings (1955) to date. Membership stands at 71 . 